\section{Palæolithic Man in Brittany}

IN view of recent reference to the fact that evidence of a Palæolithic Age had not been found in Brittany (see Nature, Aug. 21, p. 329), it is of interest to note that M. R. Mazères records in the current number of L'Anthropologie (47, 3-4) that he has found a number of flint implements of that period, when examining the quaternary deposits of the cliffs in the bay of St. Brieuc (Côte-du-Nord). The deposits include a lower and upper loess. Of these the lower, a gray loess attributed to the Riss glaciation, is ravined by interglacial deposits of marine origin, with an abundance of Buccinum reticulatum, and evidence of a superimposed raised beach at an altitude 8-9 metres, which would warrant an attribution to Mousterian, or Tyrrhenian II. Above this, and at times associated with traces of the raised beach, is the upper loess, showing evidence of two periods of deposition. In the earlier deposits of this phase were found a dozen flint implements of Mousterian facies, with flakes of diabase and other stone of the same technique in working, and the tooth of a reindeer. The use of stone other than flint is attributed to the scarcity of the latter material in the neighbourhood. The later deposits yielded two well-made carinated scrapers of flint of Middle Aurignacian type. In the same horizon, but at another site, were found a reindeer tooth and the tooth of one of the Bovidæ. The attribution of the upper loess to Würm I and Würm II is thus confirmed by the character of the contained implements. M. Mazères points out that, modest as these finds are, they serve to indicate the existence of a palæolithic culture in Brittany. This is now apparently recorded for the first time; but $M$. Mazeres recalls that in 1926 Prof. Milon and the Abbé Leclerc found a mammoth tusk in the loess to the north of Pléneuf, near the location of the present finds, and with it were flints which have not been studied.

\section{Recent Archæological Excavations in Great Britain}

THE continued examination of the neolithic barrow at Chilham, Kent, known as Julaber's Grave, which is in course of excavation by Mr. R. F. Jessup on behalf of the owner, Sir Edmund Davis (see NATURE, August 7, p. 228), has brought to light further evidence regarded as confirming local tradition. The occurrence, among other finds, of equine bones and teeth (The Times, August 16) seems to afford some foundation for the belief that the remains of one hundred horses and one hundred men were buried in the barrow. An examination of the teeth, however, suggests that the horses may have been buried there at various times in a period of centuries. Excavation has ceased for this season, but will be resumed in July next. A five weeks' season of excavation at Milber Camp, Newton Abbot, conducted by the Devon Archæological Society under the direction of Mr. F. C. Cottrill, leads to the conclusion that the camp was constructed in the last century before the Roman invasion for the purpose, it would appear, of commanding the junction of two important tracks, and that it was abandoned when the Romans built a bridge over the river at Teignmouth. Among the finds brought to light in the course of the excavation were a polished stone axe, a sling stone, decorated spindle whorls and pottery. The site was reoccupied in the Middle Ages, probably by shepherds.

Two food vessels, attributed to a date of about 2000 B.C., are reported to have been unearthed by workmen employed in the Fife Redstone Quarry, Belmullo, near St. Andrews. They were found at a depth of three feet below the surface on the side of a hill. They stand about six inches high, have a diameter of about four inches, and are ornamented with a decoration of cord impressions. Operations at the Meare Lake Village, near Glastonbury, in Somerset, were resumed for the current season on August 23. Dr. A. Bulleid and Mr. H. St. George Gray are again in charge of the excavations, acting on behalf of the Somerset Archæological and Natural History Society. The work of investigation this year will be confined to the central portion of the main group of dwellings of the East Village, upon which operations have been concentrated for the last four years. Until four years ago the West Village had been the principal site of excavation. A monograph has been prepared and is about to be published on the results obtained in the period between 1910 , when the systematic examination of this site began after the close of investigations at the Lake Village of Glastonbury, and 1933, when excavation on the West Village was brought to an end. About half this part of the site had then been investigated. The excavations this year will be carried on for a period of four weeks.

\section{Excavations on the Roman Site at Wroxeter}

THE Committee of the Wroxeter Excavation Fund has issued an appeal for funds to enable it to continue excavation on the Roman site of Uriconium. Previous investigations have covered about ten acres of a total area of 200 acres. Excavations were undertaken last year on a small scale by the Shropshire Archæological Socioty. It is proposed to continue these excavations. Generous assistance has been given by Sir Charles Marston, who is president of the Shrop. shire Archæological Society, and subscriptions have been promised by the Society of Antiquaries of London and All Souls' College, Oxford. The excavation again will be directed by Miss Kathleen Kenyon, who was in charge last year. The objects of this season's operations will be the further examination of the so-called Baths building by excavation on its north side, and the identification and excavation of the east gate of the city. It is anticipated that these investigations will throw light on three important problems : the history of the defences, the plan of the city, and the line of Watling Street, which is here in dispute. Donations should be addressed to the secretary of the Fund, Mr. A. E. Cooper, 28 Claremont Hill, Shrewsbury.

\section{Industrial Research in India}

The report of the Industrial Research Bureau, Government of India, for 1936-37, covers the work of the Industrial Research Council and the research 
work at the Government Test House as well as the work of the Bureau (Delhi : Manager of Publications, 1937. 14 annas; 1s. 6d.) The Industrial Research Council is an advisory body, consisting of representatives and non-official nominees of the central, provincial and leading State Tovernments, which meets once a year to discuss policy in the co-ordination and development of research. Programmes for road research have been approved by the Council, and the development of the manufacture of casein plastics has been considered both by the Council and by the Bureau. Industrial standardization and the compilation of a list of researches in progress or contemplated in industrial laboratories are also receiving attention, and a number of prizes have been awarded by the Council for papers bearing on industrial development. The research branch of the Government Test House which deals with the research programmes suggested by the Council and other problems referred to the Bureau has completed a preliminary investigation on the characteristics which affect the setting of red lead paint. For accelerated weathering tests on various paints the weatherometer, modified to give test conditions approximately to outside weather conditions at Alipore, has been used.

SPECIAL apparatus has also been developed in India for accelerated life tests on dry cells and considerable attention has been devoted to the use of vegetable oils for internal combustion engines. A process has been developed for rendering castor oil mi cible with mineral oils of known suitability for use in such engines, and the effects of various antioxidants have been investigated. Steady progress has been made with the work of modifying the Morris and Lister engines and of equipping them with accessories to render the operating conditions fully controllable. Another section has been responsible for important investigations on the properties of petral-benzole mixtures and the effect of changes in the composition of the benzole. A number of investigations on sand, lime, surkhi, clay, etc., have been initiated. Good progress has been made with the design of the equipment for the proposed road test track at Calcutta. Separate chapters in the report deal with work on glass and on oils and soaps, the former including the improvement of glass furnaces and a survey of glass-making materials.

\section{Research in the Iron and Steel Industry}

AT the request of the Board of Trade, the Import Duties Advisory Committee has conducted an inquiry into "The Present Position and Future Development of the Iron and Steel Industry", and its report, which is full of interest, has now been issued (Cmd. 5507. London: H.M. Stationery Office, 1937. 2s. net). The report is essentially concerned with economic conditions, but its authors recognize that both the present and the future of the industry are closely bound up with scientific control and research. They express their satisfaction with the provision made for research and their hope that it will be further extended in the future. The total industrial subscription to the Iron and Steel Industrial Research Council for $1936-37$ is estimated as $£ 30,000$. As the capital of the concerns estimated to be responsible for 86 per cent of the country's output of steel in 1936 is given as $£ 126.7$ millions, this cannot be considered an excessive allowance. Several of the large steel concerns have their own research laboratories, involving a considerable expenditure, and these have actively collaborated in the investigations of the Council, thus making an indirect contribution. Full particulars of the research organization were furnished to the Committee by the Department of Scientific and Industrial Research in writing, but the seventy-three witnesses examined orally did not include a scientific metallurgist or a director of a research laboratory, and one would have welcomed a fuller appreciation in the report of the fact that the economies to be effected by scientific improvements-as, for example, in the field of refractoriesare as important as the improvements in organization to which the report, thorough as it is, is almost entirely devoted.

\section{Far Eastern Conference on Rural Hygiene}

A CoNFERENCE for Far Eastern countries on this subject was opened on August 3 by the GovernorGeneral at Bandoeng, Java. This Conference was arranged by the League of Nations Health Organisation under the presidency of Dr. T. Offringa, director of the Netherlands Indies Public Health Service, with Dr. J. Rajchman, medical director of the League Health Committee, as secretary, assisted by Dr. C. L. Park, director of the Eastern Bureau of the Health Organisation. The Conference is meeting in five sections, in which the following subjects will be discussed: ( 1 ) health and medical services: the advantages and disadvantages of training 'semiqualified' or assistant doctors to assist the qualified medical staff, and possible alternatives; (2) rural reconstruction and collaboration of the population, with the view of improving conditions of life in rural districts, a policy favoured by the Government of India and other countries; (3) sanitation and sanitary engineering, including housing, water supply, latrines, refuse disposal and fly control ; (4) nutrition, a subject of importance in the East, for it has been estimated that 75 per cent of the population of Asiatic countries exist on a diet below the standards fixed by European science; (5) measures necessary to combat specific diseases, such as malaria, plague, tuberculosis, hookworm infection, yaws and leprosy, and mental diseases; also drug addiction.

\section{The Science Museum}

BesIdes the usual statistical information regard. ing the number of visitors and attendances at lectures, notes on special exhibitions, on acquisitions and the progress of the five main divisions of the Museum, the annual report of the Advisory Council of the Science Museum for 1936 is of especial interest as it contains a review of the growth and activities 